\title{
Synthesis, Characterization and Anti-Angiogenic Effects of Novel 5-Amino Pyrazole Derivatives on Ehrlich Ascites Tumor [EAT] Cells in-Vivo
}

\author{
H. Raju' ${ }^{1}$, S. Chandrappa ${ }^{1}$, M. K. Ramakrishna ${ }^{1}$, T. S. Nagamani ${ }^{1}$, H. Ananda ${ }^{2}$, S. M. Byregowda ${ }^{2}$, \\ K. S. Rangappa ${ }^{1^{*}}$ \\ ${ }^{1}$ Department of Studies in Chemistry, University of Mysore, Manasagangotri, India; ${ }^{2}$ Institute of Animal Health and Veterinary \\ Biologicals, Hebbal, India. \\ Email: rangappaks@chemistry.uni-mysore.ac.in, rangappaks@gmail.com
}

Received November $11^{\text {th }}, 2009$; revised December $14^{\text {th }}, 2009$; accepted December $25^{\text {th }}, 2009$.

\begin{abstract}
In search of synthetic chemotherapeutic substances capable of inhibiting, retarding, or reversing the process of multi-stage carcinogenesis, we synthesized a series of novel 5-amino pyrazole derivatives 11(a-h) by a nucleophilic substitution reaction and characterized by ${ }^{1} H$ nuclear magnetic resonance (NMR), liquid chromatography mass spectrometry (LC/MS), Fourier-transform infrared (FTIR), and elemental analysis. These novel compounds were evaluated for their efficacy in inhibiting Ehrlich ascites tumor [EAT] cells in-vivo. In the present study we designed, synthesized, characterized and investigate the anti-angiogenic effects of these compounds, on Ehrlich ascites tumor [EAT] cells in-vivo. The compounds were subsequently tested for their ability to inhibit neovascularisation in chorio allantoin membrane (CAM) model. From the Structure Activity Relationship (SAR) studies, it reveals that, the substitution at $N$-terminal in pyrazole ring plays key role in the antitumor and anti-angiogenic effects.
\end{abstract}

Keywords: 1H-Pyrazol, Aryl Isothiocyanates, Ehrlich Ascites Tumor [EAT] Cells, Anti-Angiogenesis

\section{Introduction}

Angiogenesis, a physiological process involving the growth of new blood vessels from pre-existing vessels, contributes to the development and progression of various pathological conditions including tumor growth and metastasis, cardiovascular diseases, inflammatory disease and psoriasis. Down-regulation of angiogenesis has been considered to be advantageous for prevention of neoplastic growth and inflammation. Currently, anti-angiogenic strategies are based on inhibition of endothelial cell proliferation, interference with endothelial cell adhesion and migration, and interference with metalloproteinases [1].

Many researchers have been trying to screen novel anti-angiogenic principles from various natural products. Tumors can make and release many chemicals that can start angiogenesis. Using a drug that targets only one of these chemicals may not have a large effect on the cancer, but combining drugs that attack different targets may prove to be more useful. Synthetic compounds are used to control the advanced stages of malignancies but most of the compounds exhibit normal tissue toxicity with undesirable side effects and development of drug resistance is the major clinical problem.

Indian System of Medicine has many herbal preparations with versatile medicinal properties. In common with many other low-molecular weight phenolic compounds, vanillin displays antimicrobial and antioxidant properties and hence has the potential for use as a food preservative [2]. The chemo preventive effects of vanillin have been attributed to various biological properties including neutralization of carcinogenic free radicals [3] and anti-angiogenesis action [4,5]. There is some evidence for anti-mutagenic effects of vanillin, for example in suppressing chromosomal damage induced by methotrexate in the Chinese hamster V79 cell line [6]. Most studies have addressed the prognostic significance of VEGF (Vascular endothelial growth factor) expression [7]. Pyrazoles and several N-substituted pyrazoles are known to possess numerous chemical, biological, medicinal, and agricultural applications because of their versatile biological activities like antimicrobial activity [8], antitumor and antileukemia activity [9], antidepressant and anticonvulsant [10]. Amides are ubiquitous in life, as pro- 
teins play a crucial role in virtually all biological processes such as enzymatic catalysis, transport or storage, immune protection, and mechanical support. An in-depth analysis of the comprehensive medicinal chemistry database revealed that the carboxamide group appears in more than $25 \%$ of known drugs. Recently we have reported the synthesis and anti-angiogenisis studies of bioactive heterocycles [11].

In the future, such drugs may blur the line between anti-angiogenesis drugs and other forms of cancer treatment. Researchers are now looking at many different aspects of anti-angiogenesis drugs. Better understanding of these drugs will probably make them a bigger part of cancer treatment in the future. Hence there is a need to discover novel compounds that selectively kill cancer cells. Recently, attention has been toward the drug derived from plant sources which are non-toxic and accessible to common man. Hence attempts are made to synthesize compounds of natural origin.

\section{Materials and Methods}

\subsection{Chemicals and Reagents}

Unless otherwise mentioned all the chemicals used in the present study were from Sigma-Aldrich, USA. Melting points were determined using SELCO-650 hot stage melting apparatus and were uncorrected. Infrared (IR) spectra were recorded using a Jasco FTIR-4100 series. Nuclear magnetic resonance $\left({ }^{1} \mathrm{H}\right.$ NMR and ${ }^{13} \mathrm{C}$ NMR) spectra were recorded on Shimadzu AMX 400-Bruker, $400 \mathrm{MHz}$ spectrometer using $\mathrm{CDCl}_{3}$ as solvent and TMS as internal standard (chemical shift in $\delta \mathrm{ppm}$ ). Spin multiples are given as br s (broad singlet), $\mathrm{d}$ (doublet), $\mathrm{t}$ (triplet) and $\mathrm{m}$ (multiplet). Mass and purity were recorded on a $\mathrm{LC} /$ MSD-Trap-XCT. Elemental (CHN) analyses were obtained on Vario EL III Elementar. Silica gel column chromatography was performed using Merck 7734 silica gel (60-120 mesh) and Merck made TLC plates. Substituted (E)-1H-pyrazol-5-amine 11(a-h) derivatives were synthesized by the method summarized in Figure 1.

\subsubsection{Synthesis of 3-Methoxybenzaldehyde (3)}

A solution of 4-hydroxy-3-methoxybenzaldehyde (1) $(2.0 \mathrm{~g}, 6.12 \mathrm{mmol})$ in $N$, $N$-dimethyl formamide $(20 \mathrm{~mL})$ was taken, anhydrous potassium carbonate $(4.2 \mathrm{~g}, 30.6$ mmol) was added and stirred for 20-30 min and then 5-(bromomethyl)-1, 2, 3-trimethoxybenzene (2) (2.69 g, $13.4 \mathrm{mmol}$ ) was added. The reaction mixture was stirred for $6 \mathrm{~h}$ at room temperature, and monitored by TLC. Upon completion, the solvent was removed under reduced pressure; residue was taken in water and extracted with ethyl acetate. Finally water wash was given to the organic layer and dried with anhydrous sodium sulphate. The solvent was evaporated to get crude product which

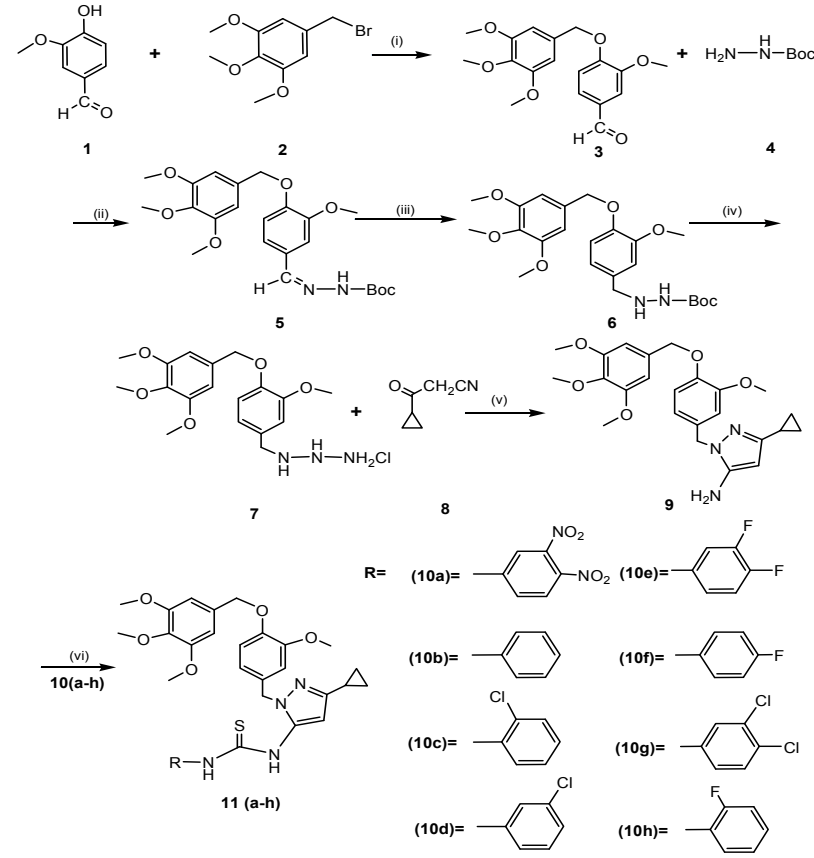

Figure 1. Reaction and reagent condition (a) $\mathrm{K}_{2} \mathrm{CO}_{3}, \mathrm{DMF} /$ r.t, 20-30 min (b) EtOH /r.t, 2-3 h (iii) 10\% Pd/c / $\mathrm{H}_{2}$ EtOAc, r.t, 3h (c) dichloromethane, ether in $\mathrm{HCl}, 3 \mathrm{~h}$ (d) EtOH/EtCOONa, reflux $80^{\circ} \mathrm{C}, 2-3 \mathrm{~h}$ (e) triethylamine, dichloromethane, aryl isothiocyanates $10(\mathrm{a}-\mathrm{h})$, r.t, 6-7 h

was purified by column chromatography over silica gel (60-120 mesh) using chloroform: methanol (9:1) as an eluent.

\subsubsection{Synthesis of $1 H$-Pyrazol-5-Amine (9)}

Initially mono boc protected 3-methoxy-benzylidene hydrazine (5) was synthesised by the condensation reaction of 3-methoxy-benzaldehyde (3) (1.0 g, 9.84 $\mathrm{mmol})$ with mono boc protected hydrazine (4) $(1.0 \mathrm{~g}$, $15.26 \mathrm{mmol}$ ). The subsequent double bond reduction was done by using $10 \% \mathrm{Pd} / \mathrm{c}$ in ethanol yielded mono boc protected 3-methoxybenzyl hydrazine (6). The deprotection of amine group was carried out by using $\mathrm{HCl}$ in ether gave free amine compound (7). Finally the key intermediate 5-amino pyrazole (9) by the cyclisation of 3-methoxybenzyl hydrazine salt (7) $(1.0 \mathrm{~g}, 5.36 \mathrm{mmol})$ and 3-cyclopropyl-3-oxopro-panenitrile (8) (0.85 g, 5.36 mmol) were taken in ethanol, and then sodium ethoxide $(1.09 \mathrm{~g}, 16.0 \mathrm{mmol})$ was added. The reaction mixture was refluxed for $2-3 \mathrm{~h}$. The progress of the reaction was monitored by TLC.

\subsubsection{General Procedure for the Synthesis and Characterization of 5-Amino Pyrazole Derivatives 11(a-h)}

To the solution of intermediate compound 9 (1 eq) in dichloromethane, triethylamine ( $3 \mathrm{eq})$ was added and 
cooled to $0-5{ }^{\circ} \mathrm{C}$ in an ice bath. Respective aryl isothiocyanate $10(\mathrm{a}-\mathrm{h})(1 \mathrm{eq})$ were added at cold condition and stirred at room temperature for 6-7 $\mathrm{h}$. The progress of the reaction was monitored by TLC. Upon completion of reaction water was added to reaction mixture and extracted with ethyl acetate. The organic layer was washed with $10 \%$ ammonium chloride solution followed by water wash and dried with anhydrous sodium sulphate. The solvent was evaporated and the crude product obtained was purified by column chromatography over silica gel (60-120 mesh) using hexane: ethyl acetate (8:2) as an eluent. Characterization of novel 5 -amino pyrazole

Table 1. Elemental analysis, $\mathrm{mp} /\left({ }^{\circ} \mathrm{C}\right)$, physical state and yield of compounds 3,9 , 11(a-h)

\begin{tabular}{|c|c|c|c|c|c|c|c|}
\hline \multicolumn{8}{|c|}{ Elemental analysis, Anal. Found (calcd) $\%$} \\
\hline Compound & Appearance & m.p/( $\left.{ }^{\circ} \mathrm{C}\right)$ & Formula & yield $/ \%$ & $\mathbf{C}$ & $\mathbf{H}$ & $\mathbf{N}$ \\
\hline 3 & white solid & $221-226$ & $\mathrm{C}_{18} \mathrm{H}_{20} \mathrm{O}_{6}$ & 95 & $65.10(65.03)$ & $6.04(6.02)$ & - \\
\hline 9 & white solid & $234-233$ & $\mathrm{C}_{24} \mathrm{H}_{29} \mathrm{~N}_{3} \mathrm{O}_{5}$ & 93 & $65.59(65.48)$ & $6.64(6.62)$ & $9.56(9.51)$ \\
\hline $11 \mathrm{a}$ & white solid & $254-256$ & $\mathrm{C}_{31} \mathrm{H}_{32} \mathrm{~N}_{6} \mathrm{O}_{9} \mathrm{~S}$ & 89 & $56.02(56.01)$ & $4.85(4.82)$ & $9.64(9.61)$ \\
\hline $11 b$ & white solid & $245-246$ & $\mathrm{C}_{31} \mathrm{H}_{34} \mathrm{~N}_{4} \mathrm{O}_{5} \mathrm{~S}$ & 91 & $64.79(62.76)$ & $5.96(5.93)$ & $9.75(9.71)$ \\
\hline $11 \mathrm{c}$ & white solid & $263-265$ & $\mathrm{C}_{31} \mathrm{H}_{33} \mathrm{ClN}_{4} \mathrm{O}_{5} \mathrm{~S}$ & 88 & $61.10(61.08)$ & $5.46(5.43)$ & $9.18(9.11)$ \\
\hline 11d & white solid & $254-255$ & $\mathrm{C}_{31} \mathrm{H}_{33} \mathrm{ClN}_{4} \mathrm{O}_{5} \mathrm{~S}$ & 85 & $61.13(61.11)$ & $5.48(5.45)$ & $9.17(9.14)$ \\
\hline $11 \mathrm{e}$ & white solid & $248-249$ & $\mathrm{C}_{31} \mathrm{H}_{32} \mathrm{~F}_{2} \mathrm{~N}_{4} \mathrm{O}_{5} \mathrm{~S}$ & 81 & $60.97(60.08)$ & $5.28(5.22)$ & $9.17(9.11)$ \\
\hline $11 \mathrm{f}$ & white solid & $255-258$ & $\mathrm{C}_{31} \mathrm{H}_{33} \mathrm{FN}_{4} \mathrm{O}_{5} \mathrm{~S}$ & 84 & $62.82(62.80)$ & $5.61(5.61)$ & $9.45(9.41)$ \\
\hline $11 \mathrm{~g}$ & white solid & $273-275$ & $\mathrm{C}_{31} \mathrm{H}_{32} \mathrm{Cl}_{2} \mathrm{~N}_{4} \mathrm{O}_{5} \mathrm{~S}$ & 79 & $57.85(57.83)$ & $5.01(5.0)$ & $8.71(8.11)$ \\
\hline $11 \mathrm{~h}$ & white solid & $267-268$ & $\mathrm{C}_{31} \mathrm{H}_{33} \mathrm{FN}_{4} \mathrm{O}_{5} \mathrm{~S}$ & 80 & $62.88(62.86)$ & $5.67(5.63)$ & $9.42(9.41)$ \\
\hline
\end{tabular}

Table 2. ${ }^{1} \mathrm{H}$ NMR and IR data of compounds 3, 9, 11(a-h)

\begin{tabular}{|c|c|}
\hline Compound & ${ }^{1} \mathrm{H}$ NMR $\left(\mathrm{CDCl}_{3}, 400 \mathrm{MHz}\right) \delta$ and IR $\left(\mathrm{KBr}, \mathrm{cm}^{-1}\right)$ data \\
\hline 3 & $\begin{array}{l}8.95(\mathrm{~s}, 1 \mathrm{H},-\mathrm{OH}), 7.92(\mathrm{dd}, 1 \mathrm{H}, J=2,8.5 \mathrm{~Hz}, \mathrm{Ar}-\mathrm{H}), 7.18(\mathrm{~s}, 1 \mathrm{H}, \mathrm{Ar}-\mathrm{H}), 6.82(\mathrm{~d}, 1 \mathrm{H}, J=8.5 \mathrm{~Hz}, \mathrm{Ar}-\mathrm{H}), 6.35(\mathrm{br} \mathrm{s}, 1 \mathrm{H}, \mathrm{Ar}-\mathrm{H}) \text {, } \\
6.15(\mathrm{br} \mathrm{s}, 1 \mathrm{H}, \mathrm{Ar}-\mathrm{H}), 5.71\left(\mathrm{~m}, 2 \mathrm{H},-\mathrm{CH}_{2}\right) 3.83\left(\mathrm{~s}, 3 \mathrm{H},-\mathrm{OCH}_{3}\right), 3.70\left(\mathrm{~s}, 3 \mathrm{H},-\mathrm{OCH}_{3}\right), 3.68\left(\mathrm{~s}, 6 \mathrm{H},-\mathrm{OCH}_{3}\right) . \\
3328,2912,1665,1583,1502,1443,1266,1124,1017 .\end{array}$ \\
\hline 9 & $\begin{array}{l}6.54(\mathrm{~s}, 1 \mathrm{H}, \mathrm{Ar}-\mathrm{H}), 6.51(\mathrm{dd}, 1 \mathrm{H}, J=2,8.5 \mathrm{~Hz}, \mathrm{Ar}-\mathrm{H}), 6.46(\mathrm{~s}, 1 \mathrm{H}, \mathrm{Ar}-\mathrm{H}), 6.15(\mathrm{~d}, 2 \mathrm{H}, J=6.5 \mathrm{~Hz}, \mathrm{Ar}-\mathrm{H}), 4.99(\mathrm{~m}, 2 \mathrm{H},-\mathrm{CH}) \text {, } \\
3.95\left(\mathrm{br} \mathrm{s}, 2 \mathrm{H},-\mathrm{NH}_{2}\right), 1.85(\mathrm{~m}, 1 \mathrm{H},-\mathrm{CH}), 0.92\left(\mathrm{~m}, 2 \mathrm{H},-\mathrm{CH}_{2}\right), 0.71\left(\mathrm{~m}, 2 \mathrm{H},-\mathrm{CH}_{2}\right) . \\
3448,2998,2942,2626,1667,1616,1516,1506,1257,1129,1024,1003,924,818,772 .\end{array}$ \\
\hline 11a & $\begin{array}{l}8.20-8.16(\mathrm{dd}, 1 \mathrm{H},-\mathrm{NH}), 8.06(\mathrm{~s}, 1 \mathrm{H},-\mathrm{NH}), 7.65(\mathrm{~s}, 1 \mathrm{H}, \mathrm{Ar}-\mathrm{H}), 7.11(\mathrm{~s}, 1 \mathrm{H}, \mathrm{Ar}-\mathrm{H}), 7.52(\mathrm{~s}, 1 \mathrm{H}, \mathrm{Ar}-\mathrm{H}), 6.1(\mathrm{br} \mathrm{s}, 1 \mathrm{H}, \mathrm{Ar}-\mathrm{H}), \\
5.21-5.18\left(\mathrm{~m}, 2 \mathrm{H},-\mathrm{CH}_{2}\right), 3.83\left(\mathrm{~s}, 3 \mathrm{H},-\mathrm{OCH}_{3}\right), 3.78\left(\mathrm{~s}, 3 \mathrm{H},-\mathrm{OCH}_{3}\right), 3.68\left(\mathrm{~s}, 6 \mathrm{H},-\mathrm{OCH}_{3}\right) . \\
3448,3318,2998,2902,1665,1584,1506,1455,1414,1276,1123,1027,925,851,722 .\end{array}$ \\
\hline 11b & $\begin{array}{l}8.20-8.16(\mathrm{dd}, 1 \mathrm{H},-\mathrm{NH}), 8.06(\mathrm{~s}, 1 \mathrm{H},-\mathrm{NH}), 6.78(\mathrm{~s}, 1 \mathrm{H}, \mathrm{Ar}-\mathrm{H}), 6.87(\mathrm{~s}, 2 \mathrm{H}, \mathrm{Ar}-\mathrm{H}), 6.62(\mathrm{~s}, 1 \mathrm{H}, \mathrm{Ar}-\mathrm{H}), 6.60(\mathrm{~s}, 1 \mathrm{H}, \mathrm{Ar}-\mathrm{H}), 6.1 \\
(\mathrm{br} \mathrm{s}, 1 \mathrm{H}, \mathrm{Ar}-\mathrm{H}), 5.21-5.18\left(\mathrm{~m}, 2 \mathrm{H},-\mathrm{CH}_{2}\right), 3.83\left(\mathrm{~s}, 3 \mathrm{H},-\mathrm{OCH}_{3}\right), 3.78\left(\mathrm{~s}, 3 \mathrm{H},-\mathrm{OCH}_{3}\right), 3.70\left(\mathrm{~s}, 3 \mathrm{H},-\mathrm{OCH}_{3}\right), 3.68\left(\mathrm{~s}, 6 \mathrm{H},-\mathrm{OCH}_{3}\right) . \\
3001,2929,1665,1598,1583,1506,1272,1127,1028,992,862,836,778 .\end{array}$ \\
\hline $11 \mathrm{c}$ & $\begin{array}{l}8.20-8.16(\mathrm{dd}, 1 \mathrm{H},-\mathrm{NH}), 8.06(\mathrm{~s}, 1 \mathrm{H},-\mathrm{NH}), 7.52(\mathrm{~s}, 1 \mathrm{H}, \mathrm{Ar}-\mathrm{H}), 6.89(\mathrm{~s}, 1 \mathrm{H}, \mathrm{Ar}-\mathrm{H}), 6.56(\mathrm{~s}, 1 \mathrm{H}, \mathrm{Ar}-\mathrm{H}), 6.40(\mathrm{~s}, 1 \mathrm{H}, \mathrm{Ar}-\mathrm{H}), 6.1 \\
(\mathrm{br} \mathrm{s}, 1 \mathrm{H}, \mathrm{Ar}-\mathrm{H}), 5.21-5.18\left(\mathrm{~m}, 2 \mathrm{H},-\mathrm{CH}_{2}\right), 3.83\left(\mathrm{~s}, 3 \mathrm{H},-\mathrm{OCH}_{3}\right), 3.78\left(\mathrm{~s}, 3 \mathrm{H},-\mathrm{OCH}_{3}\right), 3.68\left(\mathrm{~s}, 6 \mathrm{H},-\mathrm{OCH}_{3}\right) . \\
3068,2942,1676,1584,1510,1411,1257,1222,1126,1035,913,837,714 .\end{array}$ \\
\hline $11 d$ & $\begin{array}{l}8.20-8.16(\mathrm{dd}, 1 \mathrm{H},-\mathrm{NH}), 8.06(\mathrm{~s}, 1 \mathrm{H},-\mathrm{NH}), 6.95(\mathrm{~s}, 1 \mathrm{H}, \mathrm{Ar}-\mathrm{H}), 6.63(\mathrm{~s}, 1 \mathrm{H}, \mathrm{Ar}-\mathrm{H}), 6.47(\mathrm{~s}, 1 \mathrm{H}, \mathrm{Ar}-\mathrm{H}), 6.34(\mathrm{~s}, 1 \mathrm{H}, \mathrm{Ar}-\mathrm{H}), 6.1 \\
(\mathrm{br} \mathrm{s}, 1 \mathrm{H}, \mathrm{Ar}-\mathrm{H}), 5.21-5.18\left(\mathrm{~m}, 2 \mathrm{H},-\mathrm{CH}_{2}\right), 3.83\left(\mathrm{~s}, 3 \mathrm{H},-\mathrm{OCH}_{3}\right), 3.78\left(\mathrm{~s}, 3 \mathrm{H},-\mathrm{OCH}_{3}\right), 3.68\left(\mathrm{~s}, 6 \mathrm{H},-\mathrm{OCH}_{3}\right) . \\
3448,2941,1666,1583,1536,1413,1266,1128,1088,1015,996,830,730 .\end{array}$ \\
\hline $11 \mathrm{e}$ & $\begin{array}{l}8.20-8.16(\mathrm{dd}, 1 \mathrm{H},-\mathrm{NH}), 8.06(\mathrm{~s}, 1 \mathrm{H},-\mathrm{NH}), 6.72(\mathrm{~s}, 1 \mathrm{H}, \mathrm{Ar}-\mathrm{H}), 6.21(\mathrm{~s}, 1 \mathrm{H}, \mathrm{Ar}-\mathrm{H}), 6.18(\mathrm{~s}, 1 \mathrm{H}, \mathrm{Ar}-\mathrm{H}), 6.1(\mathrm{br}, 1 \mathrm{H}, \mathrm{Ar}-\mathrm{H}), \\
5.21-5.18\left(\mathrm{~m}, 2 \mathrm{H},-\mathrm{CH}_{2}\right), 3.83\left(\mathrm{~s}, 3 \mathrm{H},-\mathrm{OCH}_{3}\right), 3.78\left(\mathrm{~s}, 3 \mathrm{H},-\mathrm{OCH}_{3}\right), 3.68\left(\mathrm{~s}, 6 \mathrm{H},-\mathrm{OCH}_{3}\right) . \\
3448,3318,2998,2935,1769,1675,1667,1588,1462,1411,1278,1249,1159,1124,1023,994 .\end{array}$ \\
\hline $11 f$ & $\begin{array}{l}8.20-8.16(\mathrm{dd}, 1 \mathrm{H},-\mathrm{NH}), 8.06(\mathrm{~s}, 1 \mathrm{H},-\mathrm{NH}), 6.72(\mathrm{~s}, 2 \mathrm{H}, \mathrm{Ar}-\mathrm{H}), 6.44(\mathrm{~s}, 2 \mathrm{H}, \mathrm{Ar}-\mathrm{H}), 6.13(\mathrm{~s}, 1 \mathrm{H}, \mathrm{Ar}-\mathrm{H}), 6.1(\mathrm{br} \mathrm{s}, 1 \mathrm{H}, \mathrm{Ar}-\mathrm{H}) \text {, } \\
5.21-5.18\left(\mathrm{~m}, 2 \mathrm{H},-\mathrm{CH}_{2}\right), 3.83\left(\mathrm{~s}, 3 \mathrm{H},-\mathrm{OCH}_{3}\right), 3.78\left(\mathrm{~s}, 3 \mathrm{H},-\mathrm{OCH}_{3}\right), 3.70\left(\mathrm{~s}, 3 \mathrm{H},-\mathrm{OCH}_{3}\right), 3.68\left(\mathrm{~s}, 6 \mathrm{H},-\mathrm{OCH}_{3}\right) \text {. } \\
3316,2937,1767,1672,1588,1503,1460,1413,1245,1169,1126,1025,991 .\end{array}$ \\
\hline $11 \mathrm{~g}$ & $\begin{array}{l}8.20-8.16(\mathrm{dd}, 1 \mathrm{H},-\mathrm{NH}), 8.06(\mathrm{~s}, 1 \mathrm{H},-\mathrm{NH}), 6.96(\mathrm{~s}, 1 \mathrm{H}, \mathrm{Ar}-\mathrm{H}), 6.41(\mathrm{~s}, 1 \mathrm{H}, \mathrm{Ar}-\mathrm{H}), 6.28(\mathrm{~s}, 1 \mathrm{H}, \mathrm{Ar}-\mathrm{H}), 6.1(\mathrm{br}, 1 \mathrm{H}, \mathrm{Ar}-\mathrm{H}), \\
5.21-5.18\left(\mathrm{~m}, 2 \mathrm{H},-\mathrm{CH}_{2}\right), 3.83\left(\mathrm{~s}, 3 \mathrm{H},-\mathrm{OCH}_{3}\right), 3.78\left(\mathrm{~s}, 3 \mathrm{H},-\mathrm{OCH}_{3}\right), 3.68\left(\mathrm{~s}, 6 \mathrm{H},-\mathrm{OCH}_{3}\right) . \\
3448,3207,2998,2942,1667,1616,1516,1506,1278,1257,1129,1024,1003,924,818,772 \text {. }\end{array}$ \\
\hline $11 \mathrm{~h}$ & $\begin{array}{l}8.20-8.16(\mathrm{dd}, 1 \mathrm{H},-\mathrm{NH}), 8.06(\mathrm{~s}, 1 \mathrm{H},-\mathrm{NH}), 6.78(\mathrm{~s}, 1 \mathrm{H}, \mathrm{Ar}-\mathrm{H}), 6.72(\mathrm{~s}, 1 \mathrm{H}, \mathrm{Ar}-\mathrm{H}), 6.60(\mathrm{~s}, 1 \mathrm{H}, \mathrm{Ar}-\mathrm{H}), 6.44(\mathrm{~s}, 1 \mathrm{H}, \mathrm{Ar}-\mathrm{H}), 6.1 \\
(\mathrm{br} \mathrm{s}, 1 \mathrm{H}, \mathrm{Ar}-\mathrm{H}), 5.21-5.18\left(\mathrm{~m}, 2 \mathrm{H},-\mathrm{CH}_{2}\right), 3.83\left(\mathrm{~s}, 3 \mathrm{H},-\mathrm{OCH}_{3}\right), 3.78\left(\mathrm{~s}, 3 \mathrm{H},-\mathrm{OCH}_{3}\right), 3.70\left(\mathrm{~s}, 3 \mathrm{H},-\mathrm{OCH}_{3}\right), 3.68\left(\mathrm{~s}, 6 \mathrm{H},-\mathrm{OCH}_{3}\right) . \\
3318,2935,1769,1675,1588,1506,1462,1411,1249,1159,1124,1023,994 .\end{array}$ \\
\hline
\end{tabular}


derivatives are tabulated in Tables $\mathbf{1}$ and $\mathbf{2}$.

\subsection{Biology: in-Vivo Anti-Cancer and Angio-Inhibitory Effects of Synthetic Novel 5-Amino Pyrazole Derivatives 11(a-h)}

Animals and tumor model: Inbred Swiss albino mice, 6-8 weeks old, weighing $25 \pm 5 \mathrm{~g}$ of either sex, were used for the experiments. They were bred and maintained in the animal house, Institute of Animal Health and Veterinary Biologicals, Hebbal, Bangalore, India. Ehrlich ascites tumor was grown in adult Swiss albino mice intraperitoneally (ip). Cell viability was tested by trypan blue exclusion assay. Experimental animals were prepared by injecting $5 \times$ $10^{6}$ viable tumor cells into intraperitoneal cavity of Swiss mice. Tumor growth was followed by recording the animal weights. EAT cells begin their exponential growth phase from the $7^{\text {th }}$ day after tumor cell injection and the animal succumbs to the ascites tumor burden on day 16-20 after injection.

Compounds: Synthetic 5-amino pyrazole derivatives 11(a-h) were used as compounds for the experiments. The compounds were weighed and dissolved in $0.1 \%$ DMSO to get required concentrations. The compound treatments were initiated on the day 7 of tumor transplantation on the advanced stage of tumor when the cells enter into exponential growth period.

Animal survival: After 7 days of tumor cell injection, the animals were divided into groups of 10 each and were treated as follows: control: $0.2 \mathrm{ml}$ of $0.1 \%$ DMSO was given on day 7, 9, and 11 of tumor transplantation. Compound treated groups- the compounds 11(a-h) were given to different groups of tumor bearing mice. The compound $100 \mathrm{mg} / \mathrm{kg}$ body wt was injected intraperitoneally (ip) into the mice using 26 gauge needle on day 7 , 9 , and 11 of tumor transplantation. All the mice were weighed on the day of tumor inoculation and at weekly intervals. Animal survival was recorded up to 40 days. The tumor response was assessed on the basis of MST and increase in life span (\% ILS). Median survival time (MST) and \% ILS were calculated from the mortality data within the observation period. Increase in life span was calculated by the formula.

$\%$ ILS $=\underline{\text { MST of treated group }- \text { MST of control group }} \times 100$

$$
\text { MST of control group }
$$

Enhancements of life span by $25 \%$ are more over that of the control was considered as effective antitumor response [12].

Tumor growth inhibition and anti-angiogenesis: After 7 days of tumor cell injection, the animals were divided into eight groups of 10 each and the control group received $0.2 \mathrm{ml}$ of $0.1 \%$ DMSO on day 7,9 , and 11 of tumor transplantation. The compounds 11(a-h) were given to eight different groups of tumor bearing mice.
The tumor inhibitory effects of the compounds on EAT cell growth were assessed by measuring cell number and ascites volume. On day 12 injected $0.5 \mathrm{ml}$ saline into abdomen. The control and compounds treated tumor bearing mice were sacrificed, an incision was made in the abdominal region and EAT cells along with the ascites fluid were harvested into a beaker containing $2 \mathrm{ml}$ saline and centrifuged at $3000 \mathrm{rpm}$ for $10 \mathrm{~min}$ at $4{ }^{\circ} \mathrm{C}$. Subtracting the volume of saline added previously from the volume of the supernatant gave the volume of ascites fluid. After harvesting the EAT cells, the cells were resuspended in $0.9 \%$ saline and counted using a haemocytometer.

Changes in the morphology of EAT cells with Giemsa staining: EAT cells from the control and treated groups 11 $(\mathrm{a}-\mathrm{h})$ were smeared on clean glass slides, air-dried, and fixed in a solution of methanol/acetic acid (3:1). The slides were hydrated with PBS, then stained with $0.1 \%$ Giemsa solution, and observed under compound microscope.

Acridine orange/ethidium bromide staining: Nuclear staining was performed according to the method of Srinivas [13]. The EAT cells collected from both control and compounds $11(\mathrm{a}-\mathrm{h})$ treated groups were smeared on clean glass slides, air-dried, and fixed in a solution of methanol/acetic acid $(3: 1)$. The slides were hydrated with PBS, and then stained with mixture of acridine orange/ethidium bromide (1:1). The cells were immediately washed with PBS and viewed under fluorescent microscope and photographed.

Anti-angiogenic effects of the compounds in peritoneal angiogenesis: The peritoneum of the mice was cut open and the inner lining of the peritoneal cavity were examined for angiogenesis in both control and compounds 11(a-h) treated tumor bearing mice and photographed.

Histopathology of mice peritoneum tissue: Peritoneal tissues from tumor bearing control mice and mice treated with compounds $11(\mathrm{a}-\mathrm{h})$ were fixed in $10 \%$ formalin, embedded in paraffin, and $5-\mu \mathrm{m}$ sections were routinely stained with haematoxylin and eosin. The sections were observed under low power (10X) of light microscope to identify the highly vascularized areas. The micro vessel density (MVD) was counted in 10 fields of these vascularized areas under high power (40X) and the average MVD/HPF was noted.

Angioinhibitory effects of the compounds on in vivo chorio allantoin membrane assay: CAM was performed according to the method of Chandru and Sharada [14]. The fertilized eggs were divided into different treatment groups. Control, the saline treated group, and compound treated groups with minimum of six eggs in each group were maintained separately and observed. The fertilized eggs were incubated for 5 days at $37{ }^{\circ} \mathrm{C}$ in a humidified and sterile atmosphere. A window was made under aseptic conditions on the egg shell to check for the proper de- 
velopment of the embryo. The windows were resealed and incubation was continued. On day 11 the windows were opened and the compounds $11(\mathrm{a}-\mathrm{h})(0.1 \mathrm{mM})$ or vehicle was loaded on the cover slips separately, air-dried, and inverted over the CAM and the windows were closed. The windows were resealed and the embryo was allowed to develop further. The windows were opened and observed on day 13 and inspected for changes of MVD in the area under cover slip and examined under a microscope for avascular zone and photographed.

Statistical analysis: All data were analyzed by one-way ANOVA. Values of $p<0.05$ were considered significant.

\section{Results}

\subsection{Tumor Growth Inhibition of Ehrlich Ascites Tumor in-Vivo}

Animal survival (Table 3): The vehicle 0.1\% DMSO did not have any effect on the tumor growth. All the animals in vehicle treated controls developed tumor and died within 16-20 days. The median survival time (MST) was 18 days. All the treatments produced significant increase in MST and \% ILS compared to control $(\mathrm{p}<0.01)$. Three doses of 11(a-h) treatments on 7, 9, and 11 days after tumor transplantation showed effective antitumor response (>25\% ILS) and resulted in $48 \%, 34 \%$, and $28 \%$ ILS, respectively. However the compound 11a exhibited higher tumor inhibitory effect and showed 32 days of MST with $77 \%$ ILS. The weight changes were signifi-

Table 3. Effect of synthetic novel 5-amino pyrazole derivatives 11(a-h) on survival of mice bearing Ehrlich ascites tumor

\begin{tabular}{lccc}
\hline Treatment groups & MST (days) $^{\mathbf{a}}$ & ILS (\%) & Av. wt $\mathbf{t}^{\mathbf{b}}$ changes \\
\hline $\begin{array}{l}\text { 1. Control } \\
\text { (0.1\% DMSO) }\end{array}$ & 18 & ------ & +11.32 \\
2. $11 \mathrm{a}-100$ & $\mathbf{3 2 . 8 ^ { * * }}$ & $\mathbf{7 7 . 7}$ & $-\mathbf{4 . 4} \mathbf{4}^{* *}$ \\
3. $11 \mathrm{~b}-100$ & $28.7^{* *}$ & 68.2 & $-3.2^{* *}$ \\
4. $11 \mathrm{c}-100$ & $27.5^{* *}$ & 70.6 & $-2.8^{* *}$ \\
5. $11 \mathrm{~d}-100$ & $28.2^{* *}$ & 71.9 & $-2.9^{* *}$ \\
6. $11 \mathrm{e}-100$ & $\mathbf{3 1 . 2 * *}$ & $\mathbf{7 7 . 2}$ & $-\mathbf{4 . 2} * *$ \\
7. $11 \mathrm{f}-100$ & $29.6^{* *}$ & 73.2 & $-3.1^{* *}$ \\
8. $11 \mathrm{~g}-100$ & $\mathbf{3 0 . 3}$ & $\mathbf{7 6 . 8}$ & $-\mathbf{3 . 6} * *$ \\
9. $11 \mathrm{~h}-100$ & $23.9^{* *}$ & 63.8 & $-2.3^{* *}$ \\
\hline
\end{tabular}

11(a-h)-100 indicates dose in $\mathrm{mg} / \mathrm{kg}$ body wt. Vehicle or compounds were administered on day 7, 9, and 11 after tumor cell inoculation to different treatment groups of 10 animals each. ${ }^{a}$ Median survival time (MST) and ILS \% was calculated from the mortality data within the observation period. ${ }^{\text {b }}$ Determined on $12^{\text {th }}$ day of treatment.** Significant from control $(\mathrm{p}<0.01)$. cantly higher in compound treated groups compared to control (Table 3) indicating the effect of the compounds in preventing the tumor growth. The treated groups showed reduction in body weight due to decrease in tumor burden however no side effects were observed.

\subsection{Ascites Volume and Cell Number (Figure 2)}

The inhibitory effect of 11(a-h) on EAT cells in vivo was further examined in terms of total volume of ascites and number of cells in mice treated with vehicle or compounds. The mean value of cell number and ascites volume in control animals was found to be $1820.30 \pm 0.65 \times 10^{6}$ cells/ mouse (Figure 2(a)) and $9.24 \pm 0.30 \mathrm{ml}$, respectively (Figure 2(b)). All the compound treatments showed significant decrease in ascites volume and cell number compared to control $(\mathrm{p}<0.01)$. The compound 11a treated group which demonstrated highest \% ILS (Table 3) showed maximum reduction in cell number and ascites volume compared to other compounds treated groups.

\subsection{Changes in the Morphology of EAT Cells (Figure 3)}

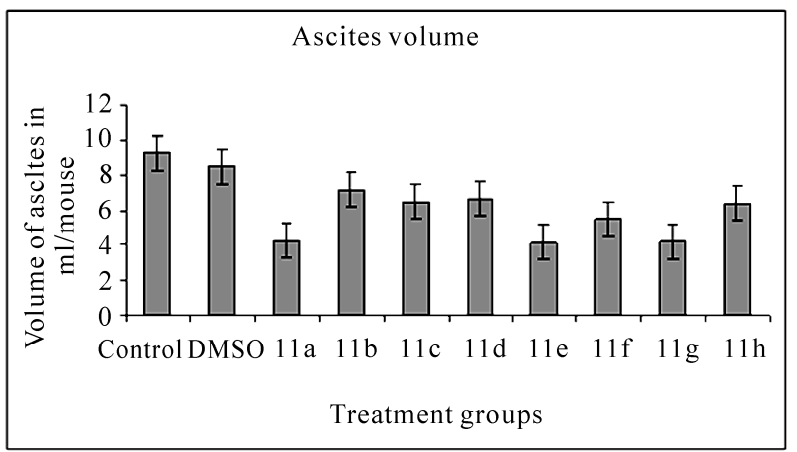

(a)

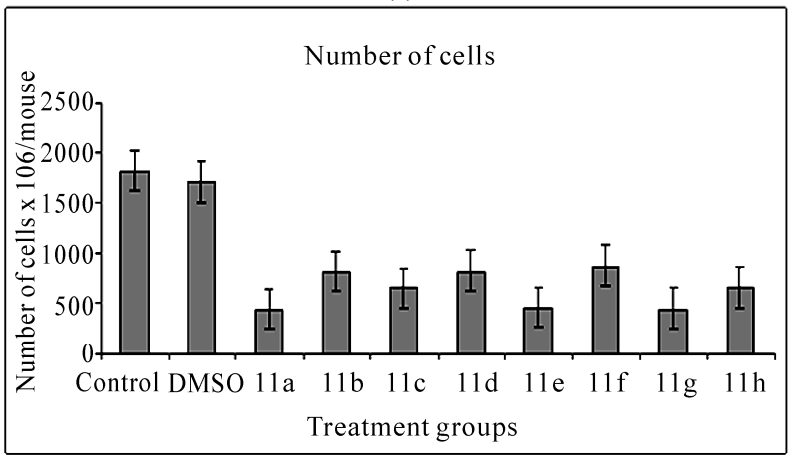

(b)

Figure 2. Effects of synthetic compounds 11(a-h) on ascites volume and cell number of EAT bearing mice. The bar graph represents the effect of the compounds on ascites volume (a) and cell number (b). All the treatments showed a significant difference in ascites volume and cell number from the control and DMSO $(p<0.01)$. The error bars represent standard deviation of the mean 


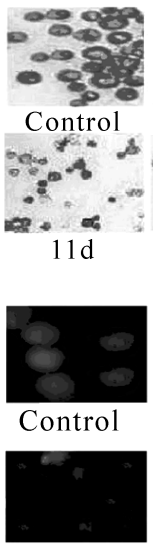

$11 \mathrm{~d}$

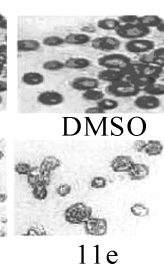

$11 \mathrm{e}$

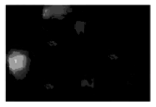

DMSO

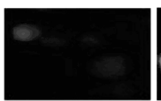

$11 \mathrm{e}$

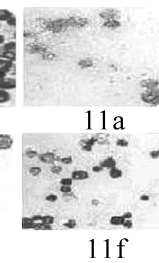

(a)
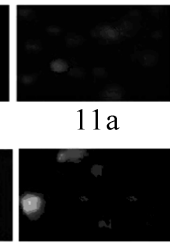

$11 \mathrm{f}$
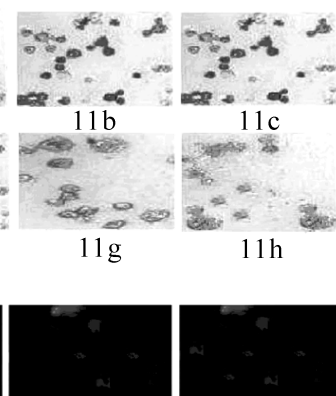

$11 \mathrm{~b}$

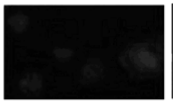

$11 \mathrm{~g}$

$11 \mathrm{~h}$ (b)

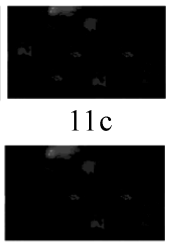

Figure 3. Changes in the morphology of EAT cells after treatment with synthetic 5-amino pyrazole derivatives. EAT cells with or without compounds 11(a-h) treatment in-vivo were washed with PBS, fixed, and stained with Giemsa stain (a) or with mixture of acridine orange: ethidium bromide (b). The cells were viewed under compound or fluorescent microscope and photographed. The apoptotic bodies and condensed nuclei are evident in the compound treated groups

The inhibitory effect of synthetic $11(\mathrm{a}-\mathrm{h})$ on EAT cell growth may be due to induction of apoptosis. The EAT cells were stained with Geimsa or with nuclear stain (acridine orange: ethidium bromide) and the slides were observed under microscope and photographed. The apoptotic bodies and nuclear condensation are evident in compound treated groups.

\subsection{Inhibition of Tumor Induced \\ Neovascularisation (Figures 4(a) and 5)}

Significant inhibitions of blood vessel formation were observed in the peritoneal wall of compound treated mice compared to control (Figure 4(a)). The MVD (Figure 5) studies using haematoxylin and eosin stained peritoneal wall sections demonstrated significant decrease in MVD count in all the compounds $11(\mathrm{a}-\mathrm{h})$ treated groups compared to control $(\mathrm{p}<0.01)$. The strong angioinhibitory effect of the compounds was evident in this study.

\subsection{Angioinhibitory Effects on CAM Assay (Figure 4(b))}

The anti-angiogenic activity was evaluated by observing the formation of avascular zone under the cover slip (Figure 4(b)), control CAM treated with $0.1 \%$ DMSO showed no changes in vasculature. The MVD decreased in the entire compounds $11(\mathrm{a}-\mathrm{h})$ treated CAM model.

\section{Discussion}

The basic principle of cancer chemotherapy is to use drugs that have targets and preferably non overlapping toxicity. Thus a logical chemotherapeutic strategy is the

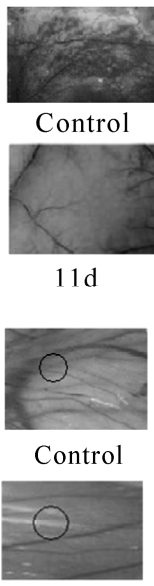

$11 d$

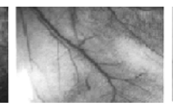

DMSO

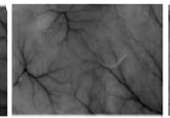

$11 \mathrm{e}$

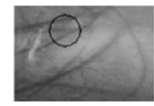

DMSO

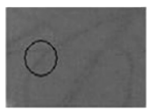

$11 \mathrm{e}$

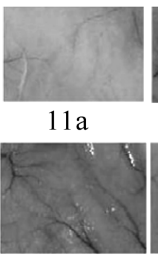

$11 \mathrm{f}$

(a)

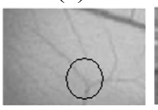

$11 \mathrm{a}$

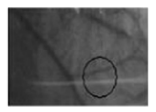

$11 f$

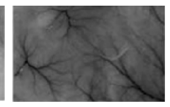

$11 b$

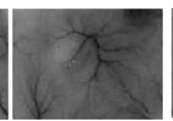

$11 \mathrm{~g}$

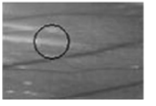

$11 \mathrm{~b}$

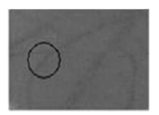

$11 \mathrm{~g}$

(b)

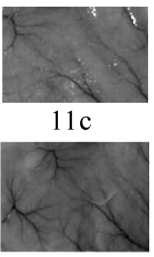

$11 \mathrm{~h}$

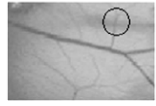

$11 \mathrm{c}$

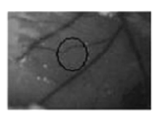

$11 \mathrm{~h}$
Figure 4. Suppression of angiogenesis in-vivo by compounds 11(a-h). Peritoneal lining of tumor bearing mice treated with vehicle $(0.1 \%$ DMSO) and were inspected for anti-angiogenesis effects. (a) Inhibitions of angiogenesis were prominent in compound treated mice compared to control. (b) CAM assay model-compounds 11(a-h) or the vehicle was applied on the CAM of 11 days old chick embryo. Decreased vasculature was observed in treated groups compared to control. Dotted circles indicate the area covered by the cover slip

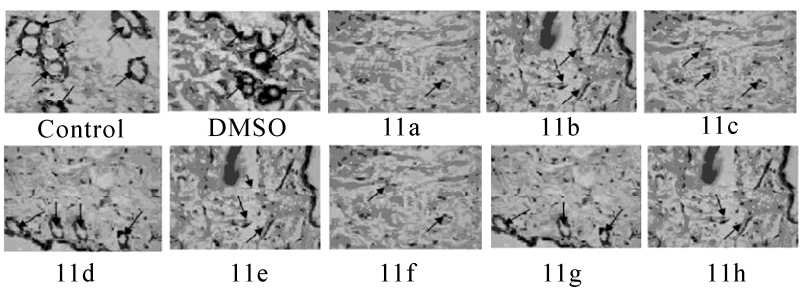

(a)

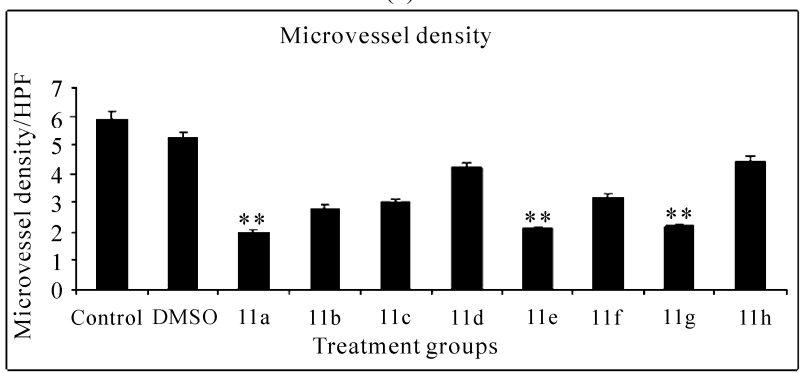

(b)

Figure 5. Histopathology and MVD count of the peritoneal wall sections of EAT bearing mice with or without in-vivo treatment of compounds 11(a-h). The arrow indicates the blood vessel present in section (a). Haematoxylin and eosin staining of peritoneal wall sections were observed to study MVD. The bar graph shows the effect of compounds on MVD count (b) of the peritoneal section of tumor bearing mice. All the compound treatments resulted in a significant decrease in MVD count compared to control $(p<0.01)$. The error bars represent standard deviation of the mean 
combined use of apoptosis inducing compounds and cytotoxic agents [15-17]. Examination of 11(a-h) aromatic regions might be critical for potential ligand-receptor binding. A reasonable approach following standard medicinal chemistry design concepts was to explore compounds with systematic differences in the carbon chain connecting to the aromatic regions and substitution of cyclopropyl ring and the nitro, chloro, fluoro phenyl groups in pyrazole ring led to the synthesis of eight novel compounds. The results on Ehrlich ascites tumor [EAT] showed that the administration of 11(a-h) on day 7, 9, and 11 after tumor cell inoculation produced effective antitumor response ( $>25 \%$ ILS). The compounds also exhibited corresponding reduction in mean ascites volume and cell number. Our findings demonstrated the potent anti-angiogenic activity of the 5-amino pyrazole derivatives against EAT in-vivo. The compounds effectively reduced the ascites tumor burden and produced no side effects. Although the antitumor property of pyrazole and its synthetic derivatives on in-vivo and in-vitro studies has been reported earlier [18]. Morphology of EAT cells after compound treatments exhibited apoptotic bodies, nuclear condensation, and intra nucleosomal fragmentation. These results indicate that the compounds $11(\mathrm{a}-\mathrm{h})$ induced inhibition of EAT cell growth was due to the induction of apoptosis in EAT cells. As the compounds are injected (ip) directly into the peritoneal cavity where the tumor is growing, the effect would be immediate and direct on the tumor cells. In the control EAT bearing mice; extensive peritoneal angiogenesis was observed which may be due to the secretion of the angiogenesis inducing factors in the ascites fluid. Involvement of VEGF in the formation of malignant ascites has been well documented [19]. Treatment of synthetic 11(a-h) to EAT bearing mice significantly decreased peritoneal angiogenesis suggesting the inhibition of the secretion of such factors and thereby preventing the formation of new blood vessels. Micro vessel density (MVD) counts have become the morphological gold standard to assess the neovasculature in tumors. MVD counts are reflective of the angioarchitectural properties of the tumor in that they are a representative of the average intercapillary distance. This is in fact an important parameter as it is the goal of an anti-angiogenic tumor therapy to reduce the intercapillary distance to a degree that it becomes rate-limiting for the growth of the tumor [20]. Haematoxylin and eosin staining of peritoneal wall tissue sections of EAT bearing mice treated or untreated with the compounds $11(\mathrm{a}-\mathrm{h})$ were examined for the MVD count. Angiogenesis is clearly evident in the inner peritoneal lining of EAT bearing mice and it is a reliable model for in-vivo angiogenesis. Hence the peritoneal linings of treated mice verified for its effect on microvasculature when compared to untreated EAT bearing mice (Figure 4(a)). In the CAM assay model compound 11a, 11e and $11 \mathrm{~g}$ induced vasculature zone formation in the developing embryos. Notably, a newly formed microvessel was regressed around the compounds implanted disc (Figure 4(b)). Quantification of VEGF (Figure 6) shows that compounds 11(a-h) has dose dependent effect on secretion of VEGF under in-vivo conditions compared to the untreated EAT bearing mice. The amount of VEGF increased in untreated EAT cells over the growth period, whereas the amount of VEGF in ascites of compounds 11(a-h) treated EAT cells did not show any significant increase in the same growth period, suggesting a dose dependent inhibition of VEGF secretion upon compounds treatment in EAT cells. Further, VEGF is considered to be one of the major stimulators of tumor angiogenesis [21].

The compounds $11(\mathrm{a}-\mathrm{h})$ with minor structural differences has exhibited varying degree of tumor growth inhibition and anti-angiogenic activities against EAT in-vivo. In the present findings, the compound 11a with the bioactive nitro, cyclopropoxy and methoxy groups at ortho, para and meta-positions in rings $\mathrm{A}$ and $\mathrm{B}$ showed potent in-vivo antitumor and anti-angiogenic activities against mouse tumor, Electron withdrawing groups such as dinitro, difluoro and dichloro at para and meta position in $11 \mathrm{a}, 11 \mathrm{e}$ and $11 \mathrm{~g}$ showed relatively significant activity, whereas $11(\mathrm{c}, \mathrm{d}, \mathrm{f}, \mathrm{h})$ groups having fewer electrons withdrawing groups of chloro (ortho), (meta) and fluoro (para), (ortho) showed moderate activity. On the other hand, as the electron withdrawing efficiency increases, the activity also increases. Compound $11 \mathrm{~b}$ without substituent on the phenyl ring of aryl isothiocyanates showed poor activity. We have briefly investigated the different structure-activity relationships (SAR) of the aryl isothio cyanates $11(\mathrm{a}-\mathrm{h})$ functionalized derivatives with different groups added on the phenyl ring. These modifications change the potency of anti-angiogenic activity profile of the synthesised compounds. Thus the structural modifications have profound influence on antitumor and angioinhibitory activities of compounds. From our findings we can conclude that $11 \mathrm{a}>11 \mathrm{e}>11 \mathrm{~g}$

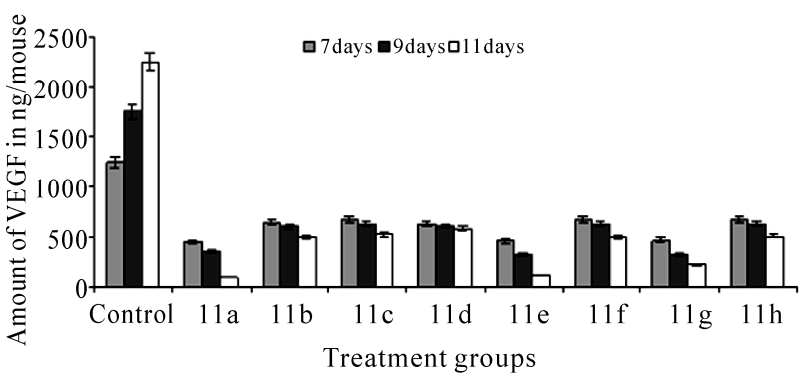

Figure 6. Effect of compounds on in-vivo production of VEGF. The bar graph shows the amount of VEGF in ascites of compounds 11(a-h) treated EAT cells 
novel 11(a-h) can be considered as promising antitumor and anti-angiogenic compounds. Thus our results show that compounds having electron withdrawing groups have more potent activity. Hence, we compare the results within same electron withdrawing nitro, fluoro and chloro group present at different position. Currently, a large variety of chemotherapeutic drugs are being used to treat cancer. Unfortunately, many compounds hold limited efficacy, due to problems of delivery and penetration, and a moderate degree of selectivity for the tumor cells, thereby causing severe damage to healthy tissues. From our studies, it is clear that compound 11a, 11e and $11 \mathrm{~g}$ has antiangiogenic effect as shown by peritoneal angiogenesis assay, chorioallantoic membrane (CAM) assay, and also from the reduction in the EAT cell number, ascites volume, and body weight of the animals in-vivo. The above study shed light toward the identification of new anti-angiogenic molecules to the cancer therapy. Further research to know the mechanism of inhibition and the modifications of the compounds 11a, 11e and $11 \mathrm{~g}$ to improve the potency is currently under progress in our laboratory.

\section{Acknowledgement}

One of the authors H.Raju is grateful to UGC Research Fellowships in Sciences for Meritorious Students Scheme (RFSMS), New Delhi for financial support under RFSMS-JRF order No. DV5/373[13]-/RFSMS/ 2008-09. The ${ }^{1} \mathrm{H}$ and ${ }^{13} \mathrm{C}$, CHN, IR and other data obtained from the instruments purchased under DST-FIST and UGC-SAP (phase II) Programmes are greatly acknowledged.

\section{REFERENCES}

[1] A. W. Griffioen and G. Molema, "Angiogenesis: Potentials for pharmacologic intervention in the treatment of cancer, cardiovascular diseases, and chronic inflammation," Pharmacol Reviews, Vol. 52, No. 2, pp. 237-268, 2000.

[2] T. Vaios, Karathanos, and I. Mourtzinos, "Study of the solubility, antioxidant activity and structure of inclusion complex of vanillin with $\beta$-cyclodextrin," Food Chemistry, Vol. 101, pp. 652-658, 2007.

[3] A. Soumyakanti, I. P. Kavirayani, and T. Mukherjee, "Physico-chemical studies on the evaluation of the antioxidant activity of herbal extracts and active principles of some indian medicinal plants," Journal of Clinical Biochemistry Nutrition, Vol. 40, No. 3, pp. 174-183, 2007.

[4] L. Kriengsak, K. Jan-Peter, and S. Tuangporn, "Vanillin suppresses metastatic potential of human cancer cells through PI3K inhibition and decreases angiogenesis in vivo," Journal of Agricultural and Food Chemistry, Vol. 57, No. 8, pp. 3055-3063, 2009.
[5] C. Keshava, N. Keshava, O. Tong-man, and N. Joginder, "Protective effect of vanillin on radiation-induced micronuclei and chromosomal aberrations in V79 cells," Mutation Research/Fundamental and Molecular Mechanisms of Mutagenesis, Vol. 397, pp. 149-159, 1998.

[6] T. S. Daniel, S. Woodrow, and M. D. David, "The antimutagenic effect of vanillin and cinnamaldehyde on spontaneous mutation in Salmonella TA104 is due to a reduction in mutations at GC but not AT sites," Mutation Research/Fundamental and Molecular Mechanisms of Mutagenesis, Vol. 480, pp. 55-69, 2001.

[7] M. Baba, H. Konno, and S. B. Nakamura, "Relationship of p53 and vascular endothelial growth factor expression to clinicopathological factors in human scirrhous gastric cancer," European Surgical Research, Vol. 30, pp. 130 137, 1998

[8] E. Akbas and I. Berber, "Antibacterial and antifungal activities of new pyrazolo [3, 4-d] pyridazin derivatives," European Journal of Medicinal Chemistry, Vol. 40, pp. 401-408, 2005

[9] S. Y. Fulmer and O. C. Allen, "Synthesis, antileukemic activity, and stability of 3-(substituted-triazeno) pyrazole -4-carboxylic acid esters and 3-(substituted-triazeno) pyrazole-4-carboxamides," Journal of Pharmaceutical Science, Vol. 60, No. 4, pp. 554-560. 1970.

[10] Z. Ozdemir, H. B. Kandilici, B. Gumusel, U. Calis, and A. Bilgin, "Synthesis and studies on antidepressant and anticonvulsant activities of some 3-(2-furyl)-pyrazoline derivatives," European Journal of Medicinal Chemistry, Vol. 42, pp. 373-379, 2007

[11] B. S. Priya, C. Anil Kumar, S. NanjundaSwamy, Basappa., S. Naveen, J. ShashidharaPrasad, and K. S. Rangappa, "2-(2-(2-Ethoxybenzoyl amino)-4-chlorophenoxy)$\mathrm{N}$-(2-ethoxybenzoyl) benzamine inhibits EAT cell induced angiogenesis by down regulation of VEGF secretion," Bioorganic \& Medicinal Chemistry Letters, Vol. 17, pp. 2775-2780, 2007.

[12] A. C. Sharada, F. E. Solomon, P. U. Devi, N. Udupa, and K. Srinivasan, "Antitumor and radiosensitizing effects of withaferin A on mouse ehrlich ascites carcinoma in vivo," Acta Oncologica, Vol. 35, pp. 95-102, 1996.

[13] G. Srinivas, R. JohnAnto, P. Srinivas, S. Vidyalakshmi, V. Priya Senan, and D. Karunagaran, "Emodin induces apoptosis of human cervical cancer cells through poly (ADP-ribose) polymerase cleavage and activation of caspase-9," European Journal Pharmacol, Vol. 473, pp. 117 $125,2003$.

[14] C. AnilKumar, Basappa, P. S. Bharathi, and K. S. Rangappa, "Pro-apoptotic activity of imidazole derivatives mediated by up-regulation of Bax and activation of CAD in Ehrlich Ascites Tumor cells," Invest New Drugs, Vol. 25, pp. 343-350. 2007.

[15] Z. Franco, P. Paola, P. Silvana, P. Graziella, S. Rosanna, and A. Federico, "Role of apoptotic response in cellular resistance to cytotoxic agents," Pharmacology \& Therapeutics, Vol. 76, No. 1, pp. 177-185, 1997. 
[16] K. Tetsuro, S. Kazunari, K. Hideaki, and M. Yukihisa, "Enhanced suppression of tumor growth by combination of angiogenesis inhibitor O-(Chloroacetyl-carbamoyl) fumagillol (TNP-470) and cytotoxic agents in mice," Cancer Research, Vol. 54, pp. 5143-5147, 1994.

[17] B. A. Teicher, S. A. Holden, G. Ara, T. Korbut, and K. Manon, "Comparison of several antiangiogenic regimens alone and with cytotoxic therapies in Lewis lung carcinoma," Cancer Chemothe Pharmacol, Vol. 38, pp. 169$177,1996$.

[18] S. Chandrappa, H. Chandru, A. C. Sharada, K. Vinaya, C. S. AnandaKumar, N. R. Thimmegowda, P. Nagegowda, M. Karuna Kumar, and K. S. Rangappa, "Synthesis and in vivo anticancer and antiangiogenic effects of novel thioxothiazolidin-4-one derivatives against transplantable mouse tumor," Medicinal Chemistry Research (In press), 2009.
[19] T. Browder, C. E. Butterfield, B. M. Kraling, B. Shi, B. Marshall, S. Michael, M. S. O'Reilly, and Folkman, "Antiangiogenic scheduling of chemotherapy improves efficacy against experimental drug-resistant cancer," Journal of Cancer Research, Vol. 60, pp. 1878-1886, 2000 .

[20] J. W. Rak, B. D. St Croix, and R. S. Kerbel, "Consequences of angiogenesis for tumor progression, metastasis and cancer therapy," Anticancer Drugs, Vol. 6, No. 1, pp. 3-18, 1995.

[21] Z. J. Shang, Z. B. Li, and J. R. Li, "VEGF is up-regulated by hypoxic stimulation and related to tumour angiogenesis and severity of disease in oral squamous cell carcinoma: In vitro and in vivo studies," International Journal of Oral and Maxillofacial Surgery, Vol. 35, pp. 533-538, 2006 